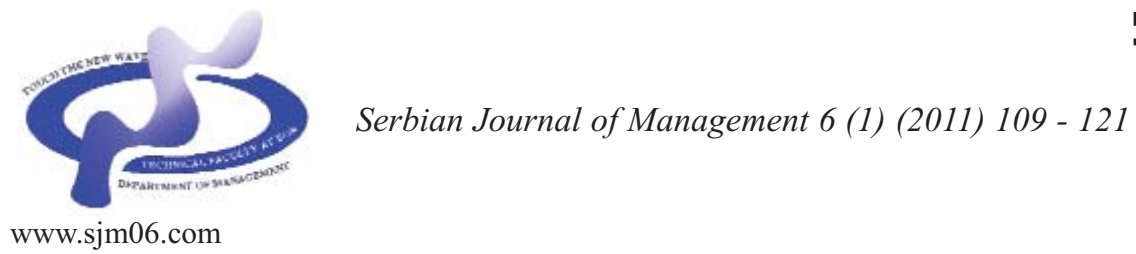

Serbian

Journal

www.sjm06.com

Letter to Editor

\title{
NON-GOVERNMENT ORGANIZATIONS: PROBLEMS \& REMEDIES IN INDIA
}

\author{
Kakumani Lavanya Latha ${ }^{a^{*}}$ and Kotte Prabhakar ${ }^{b}$ \\ ${ }^{a}$ Department of Management Studies, School of Management, Pondicherry University \\ Puducherry, India \\ $b_{\text {Department of Anthropology, Sri Venkateswara University, }}$ \\ Tirupati - 517 502, Andhra Pradesh. India
}

(Received 14. September 2009; accepted 10 August 2010)

\begin{abstract}
NGO are non-profit making agencies that are constituted with a vision by a group of like minded people, committed for the uplift of the poor, marginalized, unprivileged, underprivileged, impoverished, downtrodden and the needy and they are closer and accessible to the target groups. Фlexible in administration, quicker in decision making, timely in action and facilitating the people towards self-reliance ensuring their fullest participation in the whole process of development. The achievements and success of NGOs in various fields and the excellent work done by them in specific areas is no doubt a tremendous task that has helped to meet the changing needs of the social system. However, insprite of its achievements in various fields, NGOs are facing different problems which differ from organization to organization, region to region. In this context, an attempt is made in this paper to discuss some of the common problems faced by the NGOs and to give some remedies to overcome these problems.
\end{abstract}

Keywords: Non-Government Organization, People, Programmes, Government and Problems.

\section{INTRODUCTION}

Non-Government Organizations (NGOs) have become an irresistible global force today. The non-governmental sector, also known as voluntary sector, is growing in relation to its presence in developmental activities. Its role in the sphere of human development is now widely recognized and accepted in most parts of the universe. Basically, an NGO or voluntary organisations are non-profit making agencies that are constituted with a vision by a group of like minded people, committed for

\footnotetext{
* Corresponding author: drklavanyalatha@gmail.com
} 
the uplift of the poor, marginalized, unprivileged, underprivileged, impoverished, downtrodden and the needy and they are closer and accessible to the target groups, flexible in administration, quicker in decision making, timely in action and facilitating the people towards selfreliance ensuring their fullest participation in the whole process of development.

The rapid growth of NGOs has been clearly revealed in a major multi-nation study conducted recently by Lester Salamon, who finds it as a major economic and social force. He remarks that the global rise of the non-profit sector may be as important a development of the latter twentieth century as the development of the nation-state was in the nineteenth century. A surprisingly large scale of non-profit activity was found in almost every place the study team looked for the study. The study, covering countries like France, Germany, Hungary, Italy, Japan, the UK, the US, Brazil, Ghana, India and supports the view that the sector is undoubtedly making fast strides in many spheres of human activity. The sector, as the study shows, has turned out to be a big employer offering employment to seven million people in the US, 1.4 million in Japan, nearly one million in France, Germany and the UK combined. It forms an average of 3.4 percent of these countries total work forces employing one in every 11 workers holding service jobs. It is also found that the sector is spending huge sums varying from 1.2 percent of the GDP in Hungary to 6.3 percent in the US with an average of 3.5 percent.

Apparently, the growth of the voluntary sector has been phenomenal particular during the last two decades. The presence of the NGOs, especially those engaged in developmental efforts, has been strongly felt during these years. In fact, the involvement of NGOs in development has become indispensable today. It is estimated that about 10 percent $-\$$ eight billion-public development aid world-wide is now being routed through NGOs.

The Indian situation has not been, however, different. It the proliferation of NGOs is of any indication, the sector is expanding day to day. As per one conservative estimate, the total number of NGOs is over 0.2 million. This figure excludes organizations like trade unions, schools and hospital but includes only those registered for certification for receiving foreign assistance. The magnitude of funds the NGOs in the country handle today is another index to this growth. The annual budgets of these organizations are now not a party sum but ranges from Rs. 30 million to 5000 million.

Today, the NGOs in the country assume a conspicuous role in multifarious developmental programmes and activities. The achievements and success of NGOs in various fields and the excellent work done by them in specific areas is no doubt a tremendous task that has helped to meet the changing needs of the social system. However, insprite of its achievements in various fields, NGOs are facing different problems which differ from organization to organization, region to region. In this context, an attempt is made in this paper to discuss some of the common problems faced by the NGOs and to give some remedies to overcome these problems.

\section{NGOs IN INDIA}

NGOs or Voluntary Organizations are not a new phenomenon and the concept of 
voluntary action is very ancient. According to Inamdar, "During ancient and medieval times, voluntarism operated freely and exclusively in the fields of education, medicine, cultural promotion and even acted as succour in crises like droughts, floods, epidemics and foreign invasions" (1987).

In the early years of 19th century, voluntary agencies provided services to the under-privileged and weaker sections of the society. The areas of operation were largely in the fields of religion and social reforms. Raja Rammohan Roy (1772 -1833), Ishwar Chandra Vidyasagar (1820-1891), Sasi Pada Banarjee (1842-1925), Keshab Chandra Sen (1838-1884), Swami Dayanand Saraswati (1824-1883), Swami Vivekanand (18631902), Mahatma phule (1827-1888), Pandit Ramabai (1858-1922), Maharshi Karve (1858-1962), Sir Sayyed Ahmed Khan (1817-1898), Behramji Malbari (1853-1912) were the people who worked with dedication towards removal of caste restrictions, improving conditions of widows, women education, orphans and destitute women etc,.

In the latter part of 19th century, Christian Missioners also did pioneering work in the field of social welfare. They also took interest in spreading education among women, tribals, and others, and in improving their health and living conditions.

In the early decades of 20th century, besides relief and rehabilitation programmes in times of natural calamities like earthquakes, floods and famines, NGOs were also engaged in various fields like education, health and labour welfare. According to Chowdhry, "After Independence, leadership in India was provided by social workers who had worked under the leadership of Gandhi. As a matter fact, they were the ones who started the movement of voluntary action, both in urban and rural areas in the fields of health, education, social welfare, adult education, rural development etc.," (1987). The government undertook welfare schemes under various plans and policies, besides encouraging voluntary organizations to undertake social welfare programmes under the grant-in-aid programme and set up autonomous bodies like Central Social Welfare Board, Indian Council of Social Welfare etc.,

Some of the institutions started by Mahatma Gandhi and by the wives of the officers with the support of the British Government and those started by the Indian philanthropists, Christian Missionaries, Ramakrishna Mission etc, continued to function. Although national organizations like Indian Red Cross Society, Young Men's Christian Association (YMCA), Young Women's Christian Association (YWCA), Harijan Sevak Sangh etc, were functioning. It was around this time that several all-India level voluntary organizations such as Kasturaba Gandhi National Memorial Trust, Indian Council of Child Welfare, Youth Hostel Association, Association of Social Health etc, were set up (1999).

During the latter half of the 1970s, community organizations gained momentum. Also a radical trend emerged, with social action groups taking the view that poverty is a structural phenomenon which had to be tackled head-on through the active mobilization of the rural poor. With liberal foreign funding, social action groups proliferated throughout the late 1970s and early 1980s, and established themselves as the dominant type of NGO in some states, notably Tamil Nadu and Bihar in sharp contrast to the programme-focused approaches which had found favour from the 1960s.

From the mid-1980s, a further trend 
emerged within the NGO movement, emphasizing the importance of professional approach based on sound management, planning and co-ordination. People's participation in development was much pronounced in 1980s. A parallel development was the creation of resource agencies which work directly with the poor and also provide support services to other NGOs in the form of training, evaluation and documentation (Umukoro, 2009).

In the year 1983 a new organization called Council for Advancement of Rural Technologies (CART) was set up to improve conditions in rural areas. In 1986, CART was merged with People Action for Development in India (PADI) to form Council for the Advancement of People's Action and Rural Technology (CAPART) and its main thrust was in the areas of employment, income generation, creation of community assets and fulfilment of basic needs like housing and drinking water (2000).

In 1990s empowerment approach gained momentum. NGOs began to perform advocacy and lobbying in order to meet the challenges and threats of macro forces towards the rural poor and marginalized. As NGOs have grown in size and influence, their activities have brought them into closer contact with the Government. The NGOs are recognized by the government in rural reconstruction work. They received explicit recognition from the government in the latter half of 1980s. The Seventh Five Year Plan (1986-1990) emphasized the involvement of voluntary agencies in various proposed projects. The Eighth Plan further gave credit to NGOs and encouraged them to participate in the innovative projects like Agro Climatic Regional Planning (ACRP), the watershed development project under DPAP etc. The
Ninth Plan envisaged involving NGOs right from the planning process. In 1999 the SGSY scheme had been launched merging various Rural Development Schemes like IRDP, JRY etc., Group-lending remains the major thrust. As NGOs have done pioneering work in SHG promotion, they are being extensively involved in influencing the SHGs.

\section{REVIEW OF LITERATURE}

In India and abroad, several studies have been made on voluntary organizations working in urban as well as rural areas. Much of the literature on voluntary organizations in Indian settings has come from traditional social work.

Many of the Anthropologists, Sociologists and Political Scientists are engaged in the study of the voluntary organizations. Unfortunately, communication among the disciplines about their findings has been far from adequate.

Michael Banton's essay (1957) on the Anthropological Aspects of Voluntary Associations notes that "Voluntary Associations become more common and significant as societies advance in technology, complexity and scale". According to Banton, the associations function as a means of "organizing people in order to achieve new ends, such as the raising of capital, the regulation of prices and the provision of extra labour (Stefanovic et al., 2010).

David sills, a sociologist, emphasizes the latent functions as opposed to the manifest functions of voluntary associations and distinguishes between the functions of associations for individuals and those for society. David smith has also reviewed the 
contributions of formal voluntary organizations for society, attempting to fit his analysis into a Parson Ian framework. He asserts that the organizations perform a role in each to Talcott Parsons four structural functional categories of analysis, thus contributing to societal goal attainment, integration, pattern maintenance and adaptation.

The civic culture study which is based on over 5,000 interviews conducted in the United States, Great Britain, Germany, Italy and Mexico carried out by political scientists, Gabrial Almond and Sidney Verba (1963) suggest that differences in the political culture and socialization experiences of the citizens account for differences in the amount, kind and effects of voluntary participation in nations which are equally urban in character. For example, fewer Germans than Americans belong to organizations and of those who belong to a significantly smaller percentage of the Germans are active participating members (46 percent of the Americans compared with 16 percent of the Germans are active).

Shalini Mehta (1980) has made an attempt to analyse achievements and failures of the Government and Voluntary Agencies (VAs) in the villages of Mandla District of Madhya Pradesh in the spheres of health and education. It was found that the Voluntary Organization Banwasi Sewa Ashram is working more effectively in the field of education rather than the Government department, where as in the case of health, both Voluntary and Government Organizations failed to reach the tribal people because the tribals continue to view the modern system of medicine with superstition and contempt. However, Mehta finds a clear distinction between the efforts of the Government and Voluntary
Organizations, the latter scoring better over the former.

Alliband Terry's study of voluntary agencies (1983) as rural development agents focuses on the most widely known successful experiments by voluntary agencies such as Martandam and Sriniketan. The author's insightful comments indicate some of the major advantages and drawbacks of voluntary agencies in the national rural development efforts of the third world nations.

K.A. Suresh's (1990) study deals with the levels of participation of beneficiaries in the development programmes of select NGOs in Kerala. The author found that NGOs are not working as participatory organizations to the extent desired. The rates of participation of beneficiaries and institutional arrangements for participation are found to be very low. The beneficiaries are also found to be not keen in getting represented in decisionmaking bodies and planning process.

Vanitha Vishwanath's (1993) study evaluates and compares the role of two NGOs i.e Integrated Development Service and Gram Vikas in promoting women development. She found that Gram Vikas is working more effectively than Integrated Development Service. This is because that Gram Vikas programmes are designed in such a way that they yield quick results and are sensitive to the immediate needs of the people.

Vijay Mahajan (1994) made an attempt to examine the role of NGOs and training institutions in DWCRA programme. His study emphasizes that there is a need for the NGOs and training institutions to make DWCRA programme more effective.

Roger C.Riddel and Mark Robinson (1995) in their evaluation of sixteen projects on rural poverty alleviation carried out by 
NGOs in India, Bangladesh, Uganda and Zimbabwe provided a detailed assessment of the contribution of NGOs to alleviate rural poverty. They found that NGO projects were successful and effective in improving the social status of the poor; however, not all the projects were successful in reaching the poor.

S. Mohanan (2000) points out that NGOs have been playing a very important role in the country over the last quarter of the century in the sphere of social development. He opines that NGOs are a powerful tool in poverty alleviation and development. He considers that "The role of NGOs is more significant and pronounced in the sphere of micro credit. The rich experience of NGOs in the sphere of credit union and their grass root level involvement with the poor and their problems is a potential factor that affirms their elevated role in the sphere of micro credit" (ibid : 22-23). He believes that "NGOs will have a more elevated role in micro credit and through it the empowerment of women in days to come" (ibid: 28).

D.K. Gosh (2001) opines that attacking poverty and its reduction to an appreciable extent seems to be not manageable only by the Government sector. He considers Government Organizations need collaboration and co-operation from other than Government institutions for creating opportunities, facilitating empowerment and providing security for the poor. The author argues that, there is need for the Non Governmental organizations to fight against poverty. He prefers NGOs because they have greater accountability to the poor, as they work among the poor, while the official system is yet to be totally pro-poor.

M. Gurulingaiah (2002) observed that an NGO by name 'Abhivruddi' empowered women in rural areas of Gubbi Taluk of
Tumkur district in Karnataka state. For almost a decade the NGO has been organizing the women to form SHGs to meet their felt needs and enable them to participate in planning and implementation of their own developmental programmes. Besides, it has been conducting social and health awareness campaigns to eliminate superstitious customs, attitude and thinking related to poverty and child birth which are blocking the progress of tribal women. He concluded that the work and dedication among the women from Kadu Golla community and effort of the Abhivruddi have brought about changes in the customs, attitude, thinking and approach. Along with the NGO, the Government too has played a vital role in empowering Kadu Golla women socially and bringing them into the mainstream of the society.

M. Ramesh Singh (2004) has made an attempt to provide better understanding of NGOs working in Manipur and their problems by taking up micro level study. He conducted a survey during 2000-2001 in two tribal villages in Manipur by name Khangshin and Minou. He concluded that NGOs are playing active role in development activities in the fields of education, health and sanitation, women and children to improve the quality of life.

Pradeep Kumar (2005) observed that last two decades have been witness to tremendous growth of NGOs, both national and international. There is an urgent need that Government Organizations and NGOs act in collaboration for rural development. He supported his statement by an empirical case study of Udaipur district of south Rajasthan including two district Voluntary initiatives to support government. Both are distinct in structure and function but have common objectives to strengthen local 
governance and people's participation.

F.A Kuponiyi and A.A. Ladele (2007) explored that NGOs are very reliable in effective adaptation and transfer of technology to farmers, delivery of agricultural support services and effective vehicles for alleviating rural poverty. His study investigated the performance of two agricultural based NGOs in their effort to improve the lots of small scale resource poor farmers in Southwestern Nigeria Farmers Development Union (FADU), an enterprise building organization and Diocesan Agricultural Development Programmes (DADP), a capacity building organization were studied. The unique features of their strategies were organization of farmers into cooperative groups, attention to supply of inputs, firm arrangement for the provision of farm credit, and clientele participation in decision making. Achievement of the beneficiaries lagged behind in the case of DADP where input supply was largely left in the hands of the farmers because of its capacity-building ideology. He conducted the NGOs needed more donor assistance to enable them expand the scope of their operations.

Kris M.Y. Law (2009) in his paper investigated the key factors affecting the sustainability development strategies adoption and implementation in nongovernment organizations. Research framework linking the key factors affecting company's adoption of sustainability development strategies, the willingness and the current situation of applying sustainable strategies is proposed. Results have suggested the significant correlation between motivating factors from the four key dimensions, the willingness of NGOs' adoption of sustainable development strategies, and the impacts on the practices of companies to integrate sustainability strategies in business operations. This paper focuses on a study undertaken among a number of non-government organizations in Hong Kong. The study reveals a significant influence from the management on the willingness of adoption and sustainable development performance. This further confirms the importance on promoting the sustainability development at the operational level, with top management to provide clear strategic direction and supportive resources and environment.

\section{PROBLEMS OF NGOs}

RASS, Rural Reconstruction Society (RRS), Social Activities For Rural Development Society (SARDS), Community Action For Literacy and Livelihood (CALL), ASSIST, Rural Aid Service Organisation (RASO), Society for National Integration through Rural Development (SNIRD), Rural Development Society (RDS), Rural and Urban Development Society etc., are the some of the NGOs in India are facing the following major problems.

\subsection{Lack of Funds}

Most of the NGOs in India are suffering from paucity of funds. Government does not give cent percent grants in aid or make delay in sanctions of grants for numerous programmes. NGOs have to make matching contributions which they are some times unable to manage and are, therefore, unable to avail themselves of the grants. Now a day's charity is not so strong in the minds and hearts of the people as it was in the ancient society. This was another region for languish of funds for NGOs. 


\subsection{Lack of Dedicated Leadership}

Leadership qualities of the leaders in NGOs determine the quality and condition of the services rendered by any organization. Especially dedicated leadership, 'Leadership for the sake of Leadership' is a most important governing factor in this regard. In the post independence era, unfortunately, the NGOs faced the crisis of leadership as the leaders who pioneered voluntary action and worked for it with spirit of devotion and dedication choose to enter politics to find berths in legislatures and parliament thus creating a vacuum for dedication leadership in NGOs. With some expectations the leadership is concentrated in the hands of elderly people. The style of functioning of these elderly people exhibits authoritarianism and frustrates younger people who are embodiments of new ideas, initiatives and innovation which are not allowed to bt expressed and practiced (Mehta et al., 2010).

\subsection{Inadequate Trained Personnel}

It is believed that the personnel working in NGOs may be of personnel working in such organizations is a sense of dedication and commitment and interest in the social services. NGOs earlier were assumed to be served by unpaid social workers imbued with the spirit of service and did not require any special education or training. But the present trend who are having professional education are not interested to work with NGOs. Their vision has been changed and are interested to work in urban areas only. Therefore, it is very difficult to get trained persons who are either willing or trained to work in the rural society where most of NGOs work. Moreover, these professionally trained persons have high expectations in terms of salaries, status, opportunities for their growth in the career of their choice. More over, most of NGOs due to lack of funds cannot able to spent some more funds for giving training to the personnel employed in the organization .Some of NGOs are in fear of personnel who may shift to another big NGO after taking training from it.

\subsection{Misuse of Funds}

It is the matter of fact that some unscrupulous elements have made fortunes by floating NGOs for their personnel gains and managing grants from the government. It is a common experience that there have been serious charges of misuse and misappropriation of funds received as grantin-aid form the government, foreign donors and raised through their own resources by the most of the NGOs. These NGOs may reflect its image to other NGOs who are working with dedication and commitment.

\subsection{Monopolization of leadership}

It has been observed that there is a growing tendency towards monopolization and interlocking of leadership at the top level of voluntary action groups and organizations as is reflected in the same person being the president in one organization, secretary in the other, treasurer in the third and a member of the executive in the fourth. This interlocking of leadership can be advantageous in formulating, coordinated policies, programmes and activities, facilitating exchange of technical know-how and experience and mobilizing people for a common goal. But the greatest disadvantage of such leadership is that fresh blood is not allowed to flow into the organization and leadership. 


\subsection{Lack of Public Participation}

NGOs are meant to provide opportunities to the citizens for democratic participation but they have not been able to fulfill this obligation due to the method and manner in which they function, and failed to attract people, interested in construction work and develop channels for peoples enthusiastic participation. Some of the factors responsible for such a state of affairs are general backwardness of the people, absence of adequate number of dedicated persons, over emphasis on targets and time bound programmes, political interference and vested interests, easy availability of funds without proper planning and assessment of felt needs and safeguards for the community, distrust of agencies and workers who do not have a base in the community and are unable to win its support and lack of decentralization which could give a feeling of being partners in development rather than development being thrust from above.

\subsection{Centralization in Urban Areas}

NGOs are more developed in urban areas as compared to rural areas. The backwardness and ignorance of the rural people and lack of enthusiasm among social workers to among them in the absence of availability of minimum comforts are the two important reasons for the backwardness of the NGOs in rural areas.

\subsection{Lack of Coordination}

The absence of coordination between NGOs existing at local, state and national level has laid to the common problems such as overlapping, duplication, noncoordination etc, The absence of such a common forum also incapacitates NGOs to offer united stand against the government when it humiliates them by extraneous considerations at the behest of politicians and egoistic government officers.

Moreover, the state of affairs also does not facilitate exchange of information, data collection, research, training and publication and also does not create favorable conditions where common difficulties can be placed before the government.

\subsection{Lack of Volunteerism/Social work among Youth}

The basic characteristic of NGO is volunteerism. In early days, youth are making their career in volunteerism but that enthusiasm seems to have faded these days. The extent of volunteerism is declining day by day and turning it into professionalisation. Even the young graduates from social work are interested in making their career in professionalism. This leads to lack of efficient volunteers in NGOs.

\subsection{Modernization}

Because of modernization, professionalisation and introduction of management techniques, the traditional NGOs need certain minimum, infrastructure and administrative expenses. Unfortunately, grants-in-aid rules do not allow for such administrative expenditure except contingencies. This leads to evaporations of traditional NGOs in the country which use to lead by great leaders.

\subsection{Target orientated and time-bound Programmes}

It has been observed that the donor or 
government who sanctions grants will put target and time-bound programmes in front of NGO. Those NGOs will take the period but the qualities of service there are offering. This leads to deteriorating in quality of service and are below expected standards.

\subsection{Area of Interest}

Sometimes, NGO will prefer the donor area of interest in welfare activities going beyond his own interest or working in more than one programme. This also leads to deterioration in quality of service in particular programme.

\section{REMEDIES}

The following are the suggested remedies to the problems of the NGOs in India.

1. The government of India has to liberalize the rules and regulations of grantsin-aid and to sanction more grants to NGOs. At the same time, the government should appoint commissions of enquiry or committees to cross check the misuse of funds by NGOs. The member of committee has to supervise and monitor the activities of NGOs periodically. Political and personnel vendetta may be responsible for such investigation

2. Young graduates from universities, colleges and schools has to conduct the public seminars, meetings, symposiums etc., and use the local media to advertise the importance of volunteerism, success stories of NGOs and encourage people to participate in voluntarism.

3. At the same time, universities, colleges and schools has to collaborate with NGOs and conduct a campus interviews for the young graduates who are interested in voluntarism. NSS and NCC should encourage students to participate in voluntarism from childhood days onwards.

4. The government of India has to introduce the success stories of great leaders and their style of leadership qualities, voluntarism, dedication and commitment towards social work in the curriculum of social work departments and in the school syllabus to build leadership qualities in the coming generation. The new ideas, initiatives and innovation in the minds of youth have to help them to become great leaders.

5. There must be coordinating organizations like Association of Voluntary Association for Rural Development (AVARD), Coordination Council of Voluntary Association (CCVA) etc., to solve the problems of NGOs. These associations are to facilitate the exchange of information between the government and the NGOs.

6. In India, $65 \%$ of populations belong to rural areas. NGOs, therefore, need to operate in rural areas on a bigger scale to enlist the cooperation of village people in making their lives better. At the same time, these NGOs have to encourage the educated young graduates of rural areas to participate in voluntarism. The government has also give some special provisions for NGOs who are working in rural areas in getting eligibility conditions for grants.

7. NGOs being a welfare organization have to maintain high standard of quality in service. The government has to recognize those NGOs, by giving awards or rewards with additional grants. This would motivate the other NGOs to work efficiently.

8. Monopolization of leadership should be avoided. NGOs should recruit young and efficient people as leaders and retire the persons who are nominated members for 
very long tenures in any group or agency.

9. The government should revise the pay-scales and allowances to the personnel of NGOs. At the same time some special funds to be allotted for the NGOs to train the personnel at the grass root level.

10. The NGOs should use of latest technologies like internet, websites etc., for raising of their funds, to have mutual associations, to advertise their products and for the selection of efficient personals.

11. The government or donor while sanctioning the grants for particular programme has to considered the interest of that particular NGO. According to NGOs interest of programme, the funds to be sanctioned.

12. The government or donor should concern that particular NGO while giving target orientated or time bound programme. This leads to maintain the quality in service.

\section{CONCLUSION}

NGOs are the ones who really intend to care the uncared sections and the people at the bottom of the social stratum. Ours is an developing country which requires these type of committed, devoted and dedicated organizations for the development of the country. So, the government, the leaders, the donors, the politicians and the people should support these organizations and help them to solve their problems at the grass-root level. Than only their services are undoubtedly commendable in the uplift of the rural poor.

\title{
НЕВЛАДИНЕ ОРГАНИЗАЦИЈЕ: ПРОБЛЕМИ И ОКОЛНОСТИ У ИНДИЈИ
}

\author{
Kakumani Lavanya Latha $\mathbf{a}^{\text {* }}$ and Kotte Prabhakar \\ a Department of Management Studies, School of Management, Pondicherry University \\ Puducherry, India

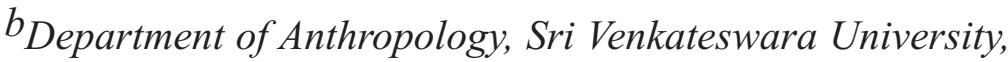 \\ Tirupati - 517 502, Andhra Pradesh. India
}

\section{Извод}

Невладине организације су организације које не стврају профит и конституишу се на основу визије групе истомишљеника, посвећених подизању нивоа живота или рада сиромашних, маргинализованих, потиснутих или непривилегованих циљних групација. Флексибилне у погледу администрације, брже у доношењу одлука, правовремене у акцији ове организације имају битну улогу у укупном развоју било ког друштва. Успех и достигнућа невладиних организација у различитим пољима је без сумње задивљујући и умногоме значајан ка постизању потреба за променама социјалног система. Ипак, и поред успеха у бројним пољима, невладине организације се сусрећу и са разним проблемима, који су различити од организације до организације и од региона до региона. У том смислу, у овом раду се дискутују проблеми функционисања овог сектора у Индији и могућа решења оваквих проблема.

Кључне речи: Невладине организације, Људи, Програми, Држава 


\section{References}

Alliband, T. (1983). Catalysts of Development. Voluntary Agencies in India, Kumarian Press, Connecticut.

Almond, G.A. \& Sidney V. (1963). The Civic Culture, Princeton University Press, Princeton.

Banton, (1957). West African City. A study of Tribal life in Freetown, Oxford University, Press, London.

Bhatia, A. (2000). Women's Development and NGOs Jaipur and New Delhi. Rawat Publications.

Bunker R. (1994). Spirit of Voluntarism: The New Parasites, Indian Express, p.8.

Chowdhry, D.P. (1987). Critical appraisal of Voluntary Effect in Social Welfare and Development since Independence, The Indian Journal of Public Administration, 333 Pp.492-500.

Gangrade, K.D. (1987). Development of Voluntary Action", Encyclopedia of Social Work, Ministry of Welfare, Government of India, New Delhi, p.227.

Ghosh, D.K. (2001). NGOs Intervention in Poverty Alleviation, Kurukshetra, March, pp.2-9.

Greene, S. (1994). Non-Profit Groups' Expanding World, The Chronicle of Philosophy, Vol.VI, No.18, p.27.

Gurulingaiah, M. (2002). Role of NGO in Empowerment of Tribal Women in Karnataka, Kurukshetra, Vol.51, No.2, Dec.Pp.30-33.

Inamdar, N. R. (1987). Role of Voluntarism in Development, The Indian Journal of Public Administration, 333, Pp.420-432.

Kevin, B. (1994). "NGOs: A Resorting to Power", Newsweek, Vol.CXXIV, No.5, August, p.14-15.

Kris, M.Y. Law, (2009). Sustainable development in Non-Governmental Organizations: Factors affecting the Management Decisions - A study in Hong Kong, International Journal of Sustainable Strategic Management,- Vol. 1, No.2, Taiwan, Pp. 204 - 219.

Kuponiyi, F.A. \& Ladele, A.A. (2007). Involvement of Non-Government Organisations(NGOs) in Food Production and Welfare of Beneficiaries: The efforts of Fadu and Dadp in South Western Nigeria, Journal of Human Ecology, Vol. 22, Dec., Pp.277-280.

Lawani, B.T. (1999). NGOs in Development (case study of Solapur District), Rawat Publications, Jaipur.

Lestar, M.S. \& Helmut, K.A. (1995). The Civil Society Sector: A New Global Force, Institute for Policy Studies, The Johns Hopkins University, Baltimore(mimeo), p.3.

Mehta, D., Sharma, J. K., Mehta, N. K., and Jain A. (2010). An empirical study on young executives' response towards pop-up and banner advertisements, Serbian Journal of Management, Vol. 5, No. 1., pp 1-188.

Mohanan, S. (2000). Micro-Credit and Empowerment of Women. Role of NGOs, Yojana, February, Pp.21-28.

Pradeep, K. (2005). Rural Development A collaboration of GOs and NGOs, Kurukshetra, Vol.53, N0.10, Pp.35-41.

Radha, K. (1993). Voluntary Agencies in a Critical Decade, Gandhi Marg, Vol.XV, No.3, p.287.

Ramesh, S.M. (2004). NGOs Activities in Tribal a5eas of Manipur. A Case Study, Vanyajati, January, Pp.3-9.

Riddel, R.C. \& Robinson. M. (1995). Non-Governmental Organizations and Rural Poverty Alleviation, Oxford. Clarendon Press.

Sachdev, D.R. (1992). Social Welfare Administration In India, Kitab Mahal 
Agency, Allahabad, p.205.

Shaline, M. (1988). Role of Voluntary and Government Organisation in Tribal Welfare. A case study of Mandala District of Madhya Pradesh. The Eastern Anthropologist, Vol.41, Pp 49-64.

Stefanovic, I., Damnjanovic, P. \& Jasko, O. (2010). The analysis of the contemporary environment impact upon organizational operations, Serbian Journal of Management 5 (1): 97 - 109.

Suresh, K.A. (1990). Participation of Beneficiaries in the Development Programmes of Non-Government Organization in Kerala, Journal of Rural Development, 95, pp.911-915.

Umukoro, F.G., Owalobi, L.K. \& Sulaimon, A.A.-H. (2009). Matching strategies to situations: Programmed and adaptive implementation approaches, Serbian Journal of Management 4 (2): 259 272.

Vanitha, V. (1993). NGOs and Women Development in Rural South India. A Comparative Analysis, Vistaar Publications, New Delhi.

Vijay, M. (1994). The Role of NGOs and Training Institution in DWCRA, NIRD, Hyderabad 